\title{
DEVELOPMENT OF THE DRYING CHARACTERISTIC COEFFICIENTS OF DRIED MARIGOLD PETALS BY USING OF AN ELECTRICAL LABORATORY DRYING SYSTEM
}

*Shokr, A. Z., *Abdel Ghaffar, E. A., *Rashwan, M. A, *Shaaban, S. S.

\section{ABSTRACT}

Marigold plant is considered one of the most important medicinal plants. It is used in pharmacological industrials, beauty tools and its pigment is utilized as a natural alternative of chemical pigment. So, the objectives of this paper are to determine the drying characteristic coefficients and investigate the chemical and sensory characteristics of dried marigold petals by utilizing electrical drying equipment at different drying air temperatures and airflow rates.

In electrical laboratory drying system (ELDS), the experiments were conducted at two controlled factors to study the drying characteristics for marigold petals, airflow rate (Qe), cu- $\mathrm{m} / \mathrm{min}$. at three levels of $(0.65$, 0.81 and $1.05 \mathrm{cu}-\mathrm{m} / \mathrm{min}$.) and drying air temperature $(T),{ }^{\circ} \mathrm{C}$ at four levels of $\left(43,48,53\right.$ and $\left.63^{\circ} \mathrm{C}\right)$. At high drying air temperature levels of $63^{\circ} \mathrm{C}$ and air flow rates ranged at $0.65-1.05$ had the best average drying rates of $(9.28-11.63 \% \mathrm{db} / \mathrm{min})$ and the best constant drying rate of (18.61-21.35\% db/min). The highest drying factors were in the range of (3.462-4.56 1/h). It had the low critical moisture content time of (2040 min.). Also it had the best sensory characteristics for color, appearance and quality. It had the best carotene concentration (Con) value range of 310.35-312.29 $\mathrm{mg} / \mathrm{g}$ with an excellent unchanging control treatment which had value of $332.39 \mathrm{mg} / \mathrm{g}$. Drying air temperature $(T),{ }^{\circ} \mathrm{C}$ had a high significant increasing effect on all drying, sensory and chemical characteristics. Meanwhile, the air flow rate had no significant effect on the previous drying characteristics.

\section{INTRODUCTION}

I $\mathrm{n}$ recent years, the medicinal plants in Egypt have an important export value, they are considered as a natural alternative to the chemical drugs because of their medical side effects. Marigold is one of the most important medicinal plants which its total production is exported to European countries.

\footnotetext{
*Ag. Eng. Dept., Fac. of Ag. (EL-Shatby), Alexandria U., Egypt.
} 
It is used in pharmacological industrials, beauty tools and its pigment is utilized as a natural alternative of chemical pigment. The total agricultural area of marigold in Egypt was $160 \mathrm{Fed}$ in 1984 and the total production was 896 ton. Meanwhile, in 1994 the total agricultural area of marigold in Egypt was 279 Fed and the total production was 2357 ton.

\section{(Agricultural Statistics, 1984 and 1994).}

Medicinal plants came in the fourth order after cotton, citrus, and potato. In 1998, the value of export medicinal plant was reached to approximately 25.9 million L.E. (Egyptian Exports Development Center, E.E.D.C., 1998).

Medicinal plants are usually spread on the ground after harvesting to be dried naturally with the direct sun's rays as a drying heat source. This process not only takes from 7 to 14 days to be completed dried but also have several problems, which effect on the plant quality. There was a few researches work on drying medicinal plants by using solar energy as a supplementary heat source. The medicinal plants are usually harvested from $80 \%$ to $90 \%$ moisture content wet basis and stored at 10 to $14 \%$ moisture content wet basis. They have to be dried carefully at low temperatures, which can easily be attained by simple solar air heaters and solar dryers.

However, it is necessary to improve marigold flowers or petal quality for insuring best export income. One of the most significant effecting method factors to improve preharvest treatments of flowering plant quality is the drying process.

Therefore, the main objectives of this research is to determine and develop the drying characteristic coefficients of dried Marigold petals by utilizing electrical laboratory drying equipment at different levels of drying air temperatures and airflow rates. And also investigate the dried marigold petals chemical and sensory characteristics.

\section{MATERIALS AND METHODS}

Fresh samples of marigold medicinal plant (Calendula officinal's), are used as flowers or medical industrials. The samples were planted on faculty of Agricultural Farm, Alexandria University, Egypt -Winter 
season. The starting of cutting flowers was begun weekly through March, April and the first two weeks of May. The marigold plant and its flowers are shown in Fig. (1).

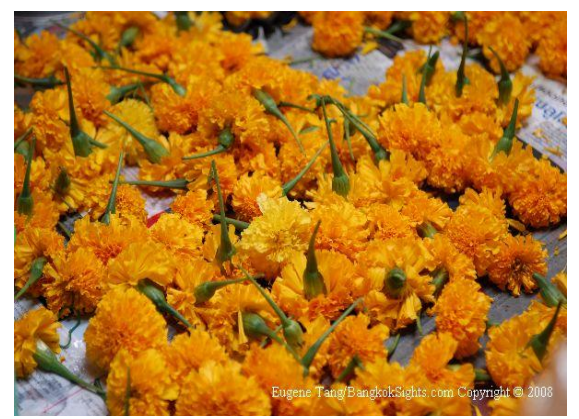

Fig. (1): Marigold flowers after cutting off.

\section{The electrical laboratory drying system:}

The laboratory dryer system consisted of three important stages as shown in Fig. (2). the air conditioning stage consisted of centrifugal fan (1.7hp. and $1200 \mathrm{rpm}$.) and a gate which could be set to deliver the required air flow rates.

In the air heating stage, three electrical heaters $(1 \mathrm{~kW} /$ heater $)$ were used in heating air with a thermostat $( \pm 1)$ to obtain the required air temperatures.

The drying stage consisted of a cylindrical shape, $15 \mathrm{~cm}$ in diameter and plexiglass. The materials were discharged in the top of the cylindrical bed or for taking material samples for moisture content measurement.

In electrical laboratory drying system, the experiments were conducted at two controlled factors were investigated to study the drying characteristics for marigold petals, airflow rate (Qe), cu-m/min. at three levels of $(0.65,0.81$ and $1.05 \mathrm{cu}-\mathrm{m} / \mathrm{min}$.) and drying air temperature (T), ${ }^{\circ} \mathrm{C}$ at four levels of $\left(43,48,53\right.$ and $\left.63^{\circ} \mathrm{C}\right)$.

\section{2- Instrumentation}

\section{2-1 Temperature measurements:}

The electrical laboratory dryer was fitted with copper-constantan thermocouples fixed at the inlet orifice of the fan, outlet of the heater, inlet of drying bed and outlet of drying bed. 
The ambient air temperature was measured by positioning three thermocouple points in a well-ventilated shaded place.

All temperatures data were measured through thermocouple thermometer digital sensors which were connected to a manual selective switch distributor which connected with ten thermocouples cables.

The wet bulb ambient air temperatures were measured by using of the ordinary thermo glass.

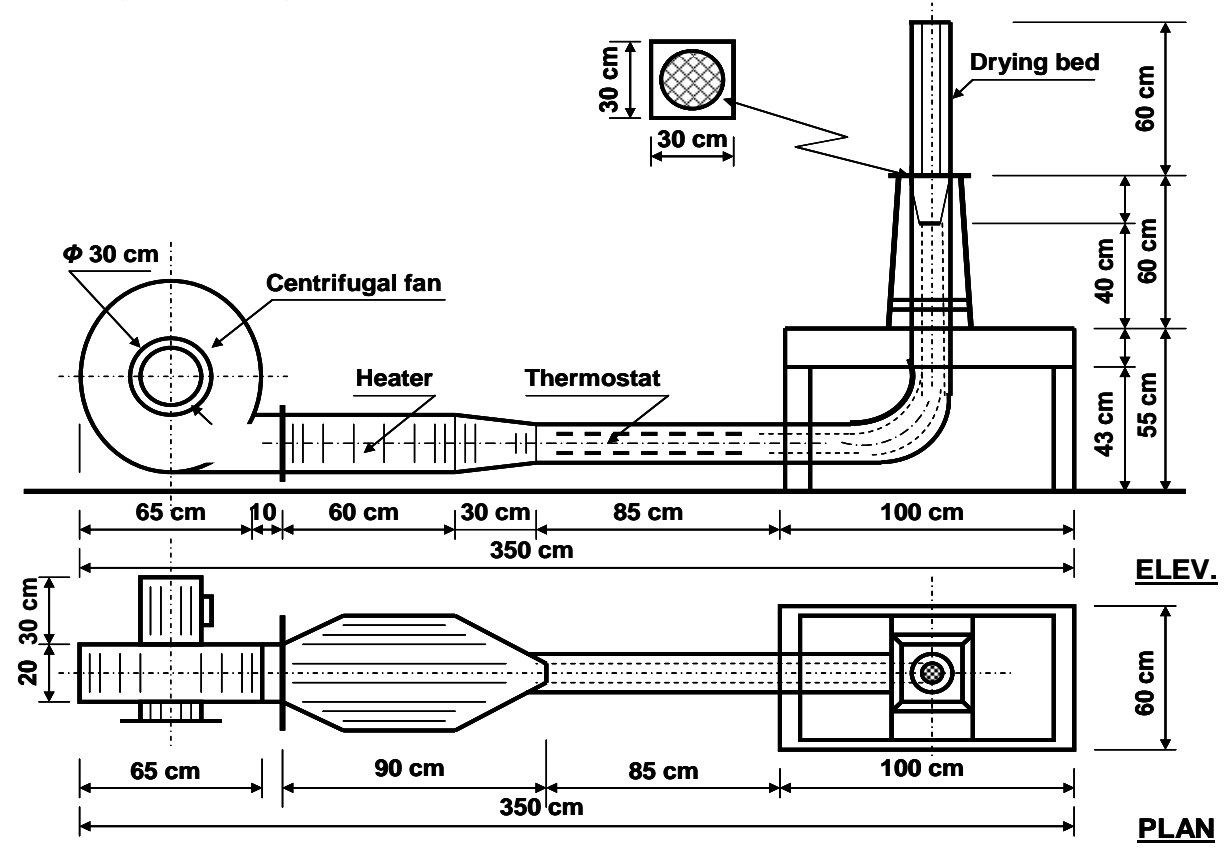

Fig. (2): Electrical laboratory dryer. (Scale 1:30)

\section{2-2 Air flow rate measurements:}

A turbo meter wind speed indicator was used to measure the air velocity and to estimate different levels of air flow rate from the basic formula:

$$
\mathbf{Q}=\mathbf{V} \times \mathbf{A}
$$

Where,

$\mathbf{Q}=$ Airflow rate, $\mathrm{m}^{3} / \mathrm{min}$.

$\mathbf{V}=$ Air velocity, $\mathrm{m} / \mathrm{min}$., and

$\mathbf{A}=$ Cross sectional area, $\mathrm{m}^{2}$ 
The velocity indicator measured the air velocity $(\mathrm{m} / \mathrm{s})$ at the inlet bed drying before and after putting the samples in the dryer.

In solar air collector, the velocity indicator measured the velocity in different levels of the out let pipe section concentrated with the solar collector to calculate its solar collector air flow rates (Qc). The apparatus also was used to measure air velocity at the four trays dryer bed to calculate their airflow rate $(\mathrm{Qb})$.

\section{2-3 Moisture content measurements:}

A $0.1 \mathrm{~g}$ balance accuracy was used to determine the moisture content for all samples by recording the sample weight for marigold petals. The moisture content was calculated basically in wet basis and dry basis by applying the following equations:

$$
\begin{aligned}
& M C(w b)=W w /(W w+W d) \times 100 \\
& M C(d b)=W w / W d \times 100
\end{aligned}
$$

Where,

$\mathrm{MC}(\mathrm{wb})$ is the moisture content (wet basis) \%

$\mathrm{MC}(\mathrm{db})$ is the moisture content (dry basis) \%

$\mathrm{Ww}$ is the water mass, $\mathrm{g}$ and;

$\mathrm{Wd}$ is the dry matter mass, $\mathrm{g}$

The initial sample weight for all experiment was $60 \mathrm{~g}$. The initial moisture content was calculated by utilizing the oven method at $105^{\circ} \mathrm{C}$. for $24 \mathrm{~h}$. (Buser, 1999).

\section{2-4 Sensory characteristics of dried Marigold petals:}

Effect of the different drying methods on sensory characteristics of Marigold petals were evaluated using the method described by Kramer and Twigg (1974).

A panel of 4 exporters of medicinal plants evaluated; the colour, appearance and general quality of samples according to the following units out of ten.

Excellent 9-10, Good 7-8, Fair 5-6, Very bad 3-4, Refused 12 


\section{2-5 Determination of total carotene content of marigold petals:}

The pigment of marigold was extracted by using Official Methods of analysis of the Association of Analytical Chemists A.O.A.C. method. Using a blender and samples which were blended in $50 \mathrm{ml}$ acetonehexane (6:4, Vol:Vol.) solvent with $10 \mathrm{ml}$ water added to prevent the samples from drying on the cup. The sample was filtrated with filtrated paper and the residue washed with small volume of acetone and hexane until colorless. It was sometimes necessary to repeat the process in order to complete extraction. The acetone was removed from the extract by washing with water. The pigment solution in hexane was brought to certain volume and measured at $450 \mu$. Spectrophotometer. The percent transmission was used to calculate the total carotenids as a beta-carotene, using a standard curve prepared with pure beta-carotene and optical density.

\section{2-6 Statistical analysis:}

The data of chemical and sensory characteristics were analyzed according to the statistical analysis of variance A.N.O.V.A. and multiple linear regression analysis as described by Baily (1994).

\section{RESULTS AND DISCUSSION}

\section{A- The electrical laboratory drying system:}

In laboratory experiments an electrical drying system, was used to heat the drying air. Two controlled factors were investigated to study the drying characteristics for marigold petals, airflow rate (Qe), cu-m/min. at three levels of $(0.65,0.81$ and $1.05 \mathrm{cu}-\mathrm{m} / \mathrm{min}$.) and drying air temperature $(\mathrm{T})$ at four levels of $\left(43,48,53\right.$ and $\left.63^{\circ} \mathrm{C}\right)$.

The relationship of data between drying time $(\mathrm{t})$, min and the average drying characteristics at air temperature $\left(\mathrm{T}=43^{\circ} \mathrm{C}\right)$ and air flow rate ( $\mathrm{Qe}=1.05 \mathrm{cu}-\mathrm{m} / \mathrm{min}$.) were plotted in Figs. (3 to 6). These experiments were started with initial moisture content of $680.64 \%$, db $(87.19 \%$, wb) and finished after $1140 \mathrm{~min}$. (19 h) whenever the moisture contents were reached to reasonable three equal values which were almost at average $12.06 \%, \mathrm{db}(10.76 \%$, wb). Such moisture content was defined as an 
equilibrium moisture content (EMC), \%. In Fig. (3), the moisture contents, $\mathrm{db}$ data were plotted and analysis versus drying time to obtain an empirical equation using a best fit method.

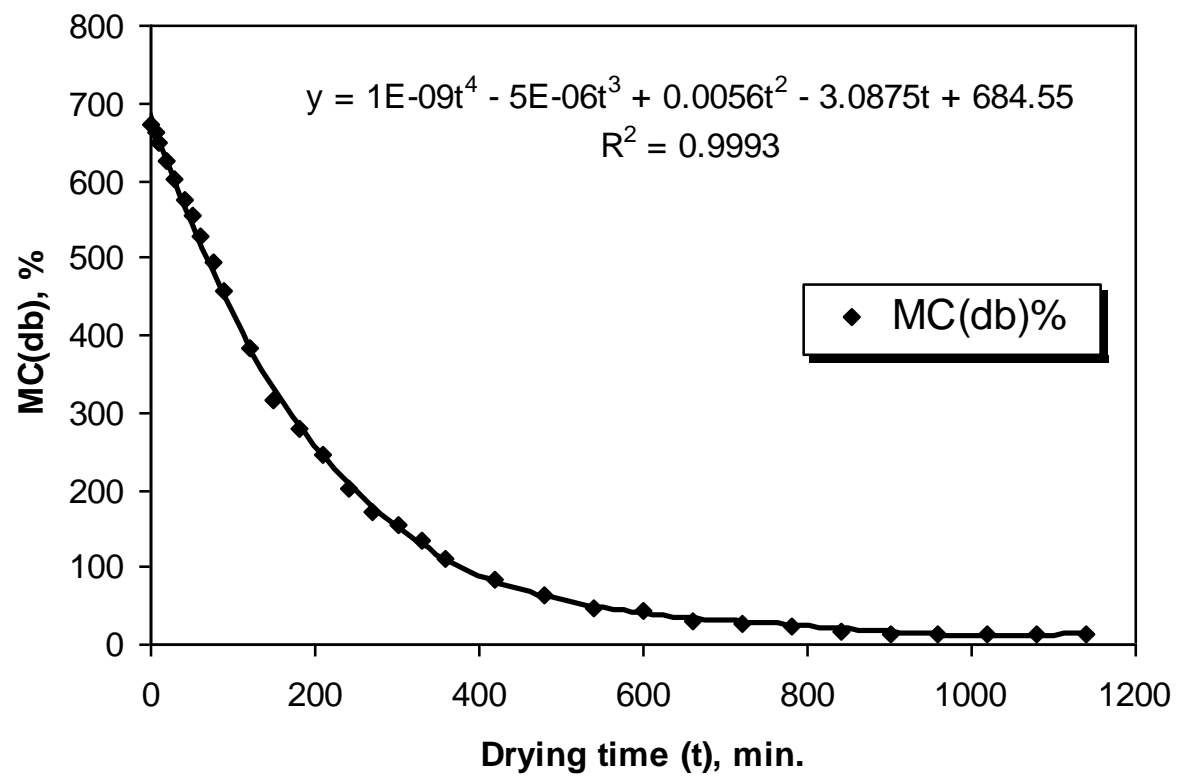

Fig. (3): Moisture content dry basis, $\mathrm{MC}(\mathrm{db}), \%$, versus drying time (t), min at drying air temperature $\mathrm{T}=43{ }^{\circ} \mathrm{C}$ and airflow rate $\mathrm{Qe}=1.05 \mathrm{cu}-\mathrm{m} / \mathrm{min}$. for marigold petals.

The drying rate data (DR), \% db/min. were estimated and fitted versus drying time in Fig. (4). It showed the drying curves for marigold petals that could be divided into two periods according to drying rate, the constant drying rate (DRc) and falling drying rate (DRf). This agreed with (Othman, 1996). The critical moisture content for this test was $384.29 \%, \mathrm{db}(79.35 \%$, wb) with average content drying rate (DRc) $=2.41 \% \mathrm{db} / \mathrm{min}$. Natural logarithmic (LNMR) and moisture ratio (MR), decimal, were presented with time in Figs. (5 and 6) and fitted into two stages related to drying rate. Moisture ratio in constant drying rate stage could be predicted according to a linear relationship as shown in Fig. (6), while in falling drying rate stage could be predicted by the following formula according to (Henderson and Perry 1976):

$M R=\frac{M C(d b)-E M C(d b)}{\operatorname{IMC}(d b)-E M C(d b)}=A_{1} e^{-K t}$ 
Where,

MR is the moisture ratio, decimal

$\mathrm{MC}(\mathrm{db})$ is the moisture content at a specific drying time (dry basis), \%

IMC ( $\mathrm{db})$ is the initial moisture content (dry basis), \%

$\mathrm{EMC}(\mathrm{db})$ is the equilibrium moisture content (dry basis), \%

A1 is an experimental constant.

$\mathrm{K}$ is the drying constant, 1/unit time.

$\mathrm{t}$ is the drying time, unit time.

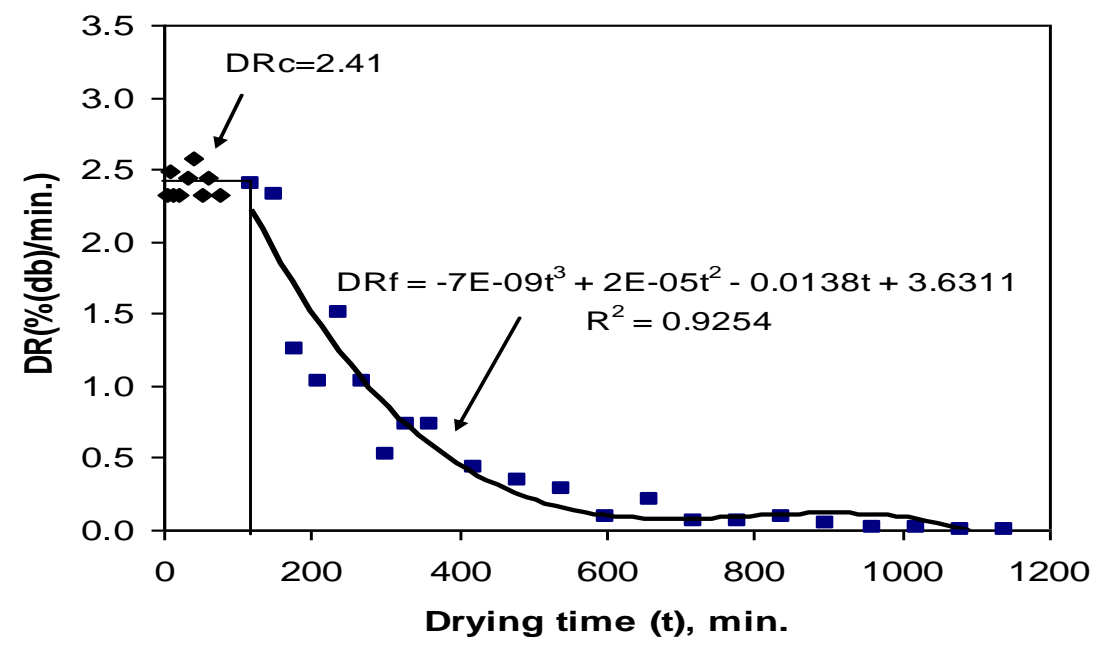

Fig. (4): Drying rate (DR), (db) \%/min, versus drying time (t), min at drying air temperature $\mathrm{T}=43{ }^{\circ} \mathrm{C}$ and airflow rate $\mathrm{Qe}=1.05 \mathrm{cu}-\mathrm{m} / \mathrm{min}$. for marigold petals.

Drying time, $t$, $\min$

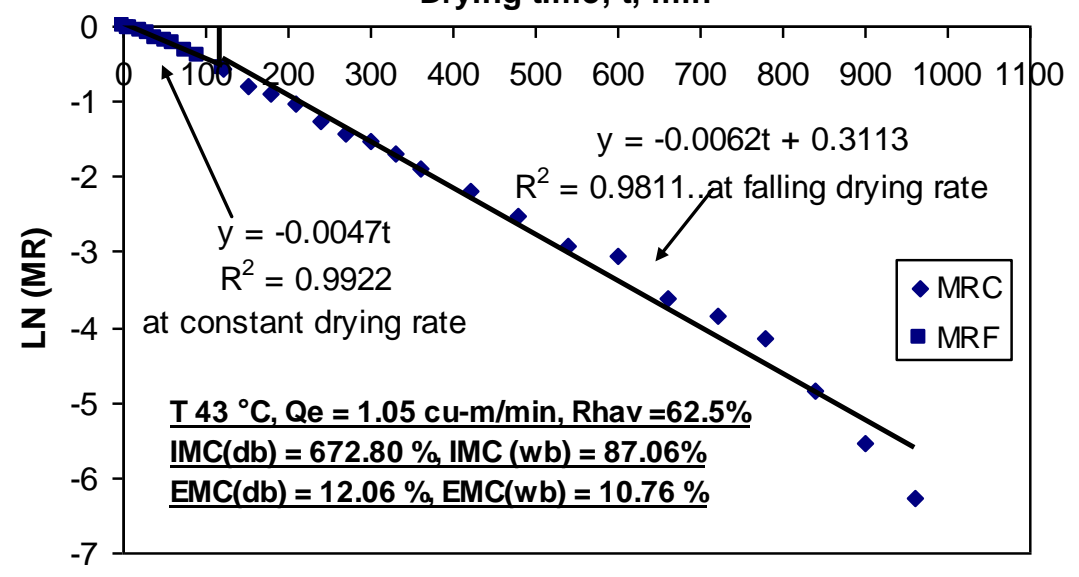


Fig. (5): Moisture ratio ( $\mathrm{LN}(\mathrm{MR})$ ), decimal, versus drying time (t), min at drying air temperature $\mathrm{T}=43{ }^{\circ} \mathrm{C}$ and airflow rate $\mathrm{Qe}=1.05 \mathrm{cu}-\mathrm{m} / \mathrm{min}$. for marigold petals.

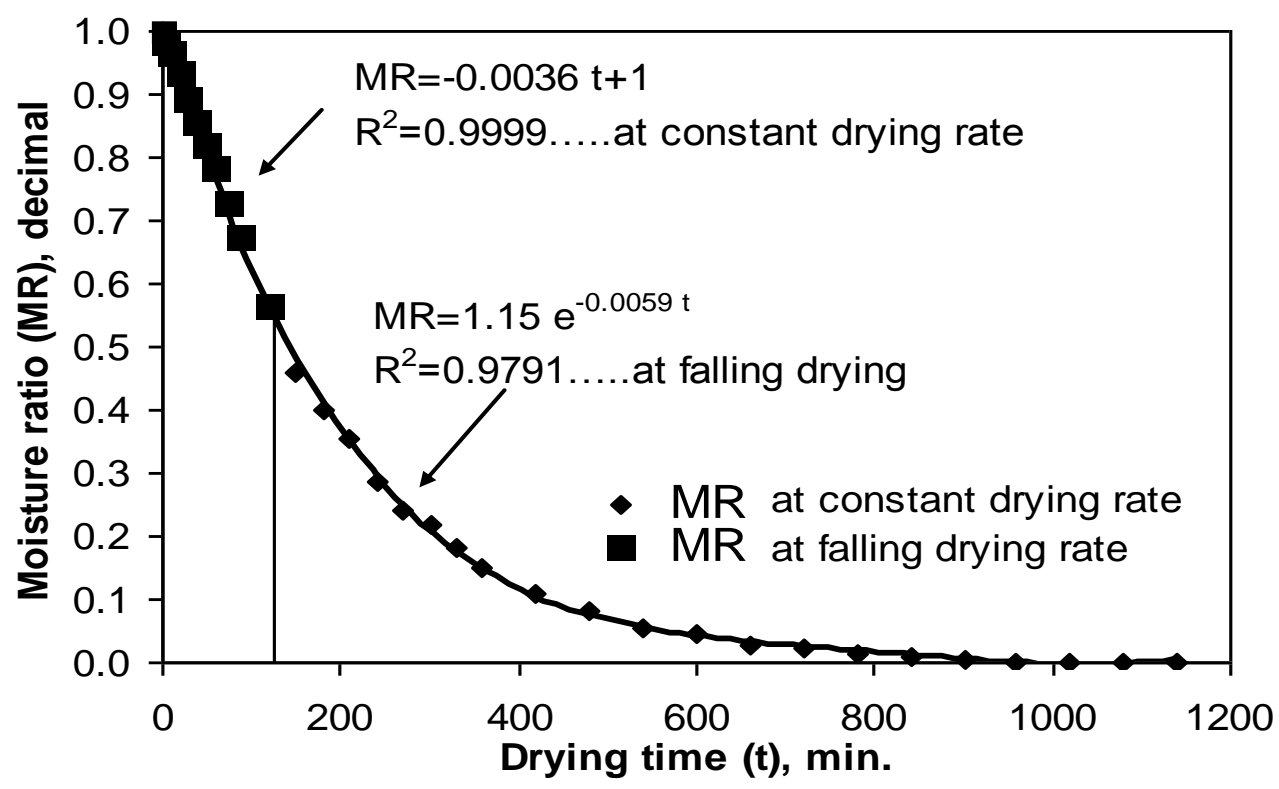

Fig. (6): Moisture ratio (MR), decimal, versus drying time (t), min at drying air temperature $\mathrm{T}=43{ }^{\circ} \mathrm{C}$ and airflow rate $\mathrm{Qe}=1.05 \mathrm{cu}-\mathrm{m} / \mathrm{min}$. for marigold petals.

The drying constant $\mathrm{K}, 1 / \mathrm{h}$ at air temperature $\left(\mathrm{T}=43^{\circ} \mathrm{C}\right)$ and air flow rate, $(\mathrm{Qe}=1.05 \mathrm{cu}-\mathrm{m} / \mathrm{min}$. $)$ was $0.3541 / \mathrm{h}$.

To study the effect of the three different levels of airflow rate (1.05, 0.81 and $0.65 \mathrm{cu}-\mathrm{m} / \mathrm{min}$ ) at constant drying air temperature, data were plotted in Figs (7-a,b,c,d), to represent the relationship between the moisture ratio as function of drying time. The shape of curves illustrated that were no significant differences as affected by the airflow rate levels. They had closely similar values. This result agreed with (Buser et al., 1999). 

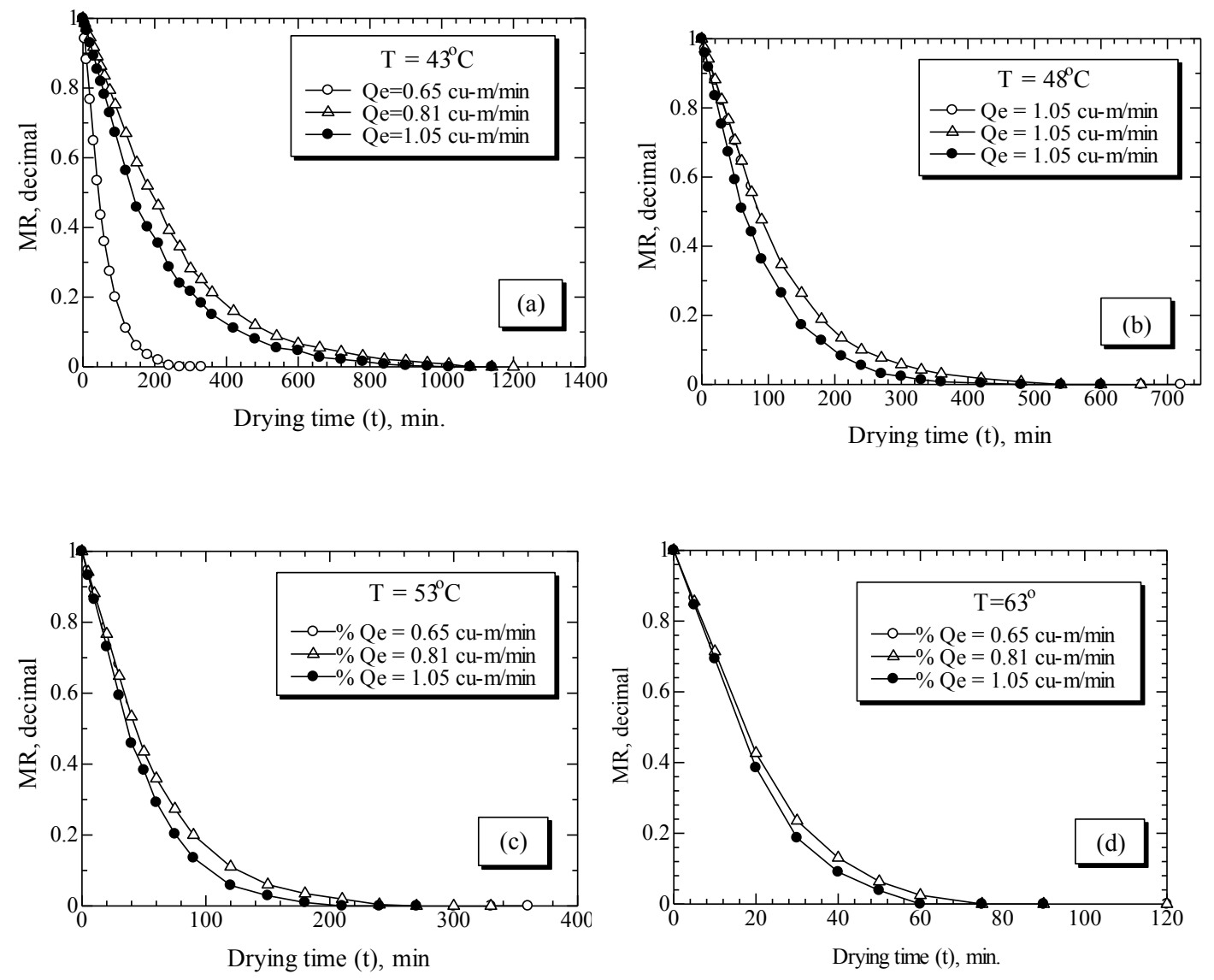

Fig. (7-a,b,c,d): The relationship of data between drying time $(\mathrm{t})$ and Moisture ratio at air temperature $(\mathrm{T})$ and air flow rate $(\mathrm{Qe})$.

Figures $(\mathbf{8 - a}, \mathbf{b}, \mathbf{c})$ represent the effect of moisture ratio as a function of drying time at different levels of drying air temperatures, $43,48,53$ and $63^{\circ} \mathrm{C}$ whenever the airflow rate was constant. The pattern of the curves showed high significant differences between air drying temperature levels. Increasing the drying air temperature increases the drying rate and decreases the drying time. This also agrees with the research work done by (Buser et al., 1999). 

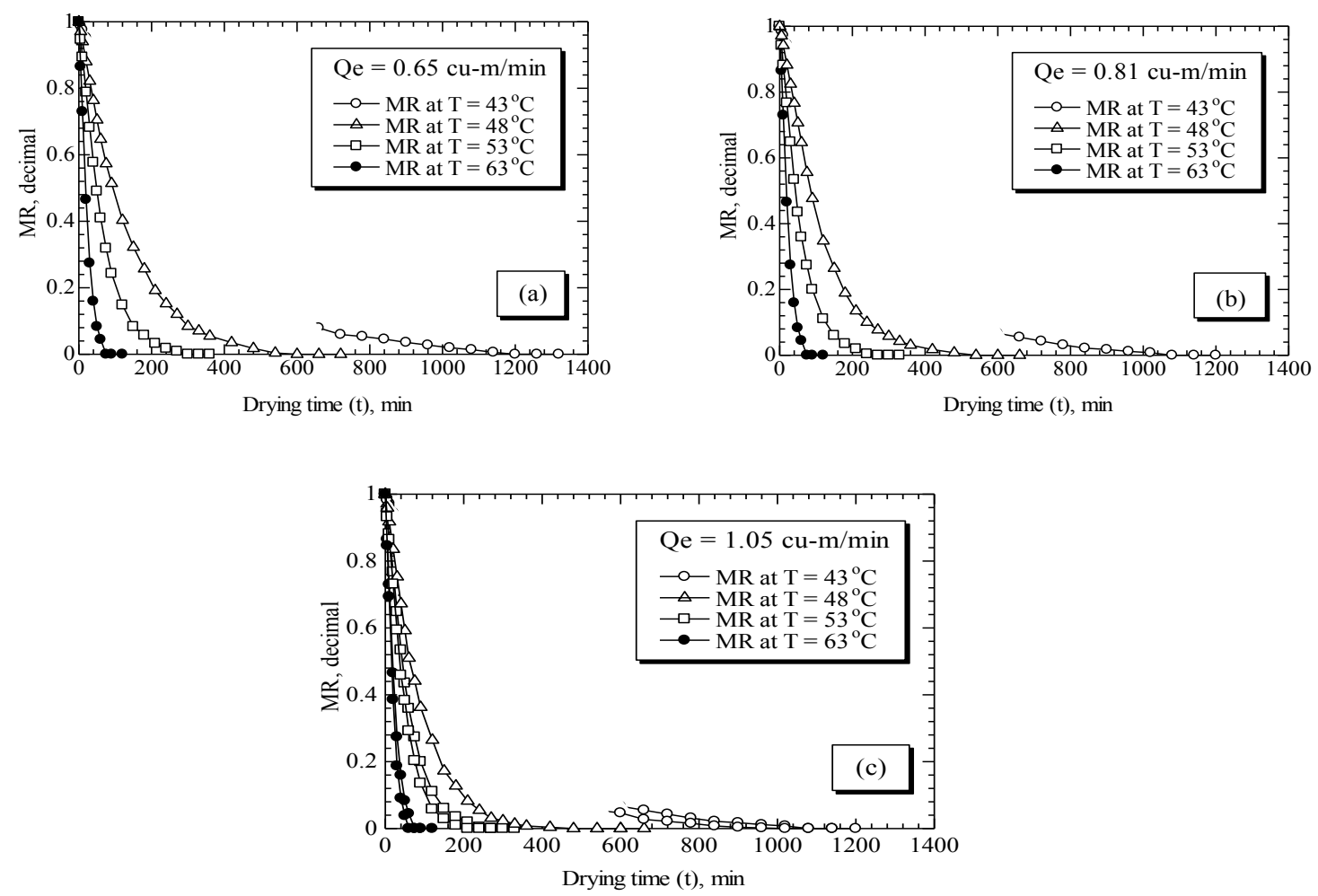

Figs. (8-a,b,c): Effect of moisture ratio as a function of drying time at different levels of drying air temperatures.

Table (1) shows the determination of drying characteristics at different levels of drying air temperature $(\mathrm{T}),{ }^{\circ} \mathrm{C}$ and air flow rate $(\mathrm{Qe}), \mathrm{cu}-\mathrm{m} / \mathrm{min}$. The initial moisture content (IMC) varied between $624.64 \%$, db (86.20 $\% \mathrm{wb})$ and $706.45 \%, \mathrm{db}(87.60 \% \mathrm{wb})$. The equilibrium moisture content (EMC) had a limited value between $8.87 \%$, db and $14.73 \%$, db $(8.15 \%, w b$ and $84 \%, w b)$. The minimum average relative humidity of ambient air was $57.1 \%$ while the maximum average relative humidity of ambient air was $66.5 \%$. The critical moisture content value was limited between $277.69 \%$, db (73.52\%, wb) and $408.45 \%$, db (80.33\%, wb). 
Table (1): Drying characteristics at different levels of drying air temperature $(\mathrm{T}),{ }^{\circ} \mathrm{C}$ and air flow rate $(\mathrm{Qe}), \mathrm{cu}-\mathrm{m} / \mathrm{min}$

\begin{tabular}{|c|c|c|c|c|c|c|c|c|c|c|c|c|}
\hline NO & $\begin{array}{c}\mathbf{T} \\
{ }^{\circ} \mathbf{C}\end{array}$ & $\begin{array}{c}\text { Qe } \\
\text { cu-m } \\
\text { /min }\end{array}$ & $\begin{array}{c}\text { IMC } \\
(\mathbf{d b}) \\
\%\end{array}$ & $\begin{array}{c}\text { EMC } \\
\text { (db) } \\
\%\end{array}$ & $\begin{array}{c}\text { ADR } \\
\text { (db) } \\
\% \\
/ \mathrm{min}\end{array}$ & $\begin{array}{c}\text { DRc } \\
\text { (db) } \% \\
/ \mathrm{min}\end{array}$ & $\begin{array}{c}\text { CMC } \\
\text { (db) } \%\end{array}$ & $\begin{array}{c}\text { CMC } \\
\text { T min }\end{array}$ & $\begin{array}{c}K \\
1 / h\end{array}$ & $\begin{array}{c}\text { TDT } \\
\mathbf{h}\end{array}$ & $\begin{array}{c}\text { EMC } \\
\text { T } \\
\text { h }\end{array}$ & $\begin{array}{c}\mathbf{R H}_{\mathrm{av}} \\
\%\end{array}$ \\
\hline 1 & 43 & 0.65 & 624.6 & 14.73 & 0.51 & 1.45 & 408.5 & 150 & 0.25 & 22 & 21 & 66.5 \\
\hline 2 & 43 & 0.81 & 654.7 & 13.21 & 0.59 & 1.77 & 389.3 & 150 & 0.29 & 20 & 18 & 54.7 \\
\hline 3 & 43 & 1.05 & 672.8 & 12.06 & 0.65 & 2.41 & 384.3 & 120 & 0.35 & 19 & 17 & 62.5 \\
\hline 4 & 48 & 0.65 & 640.7 & 11.11 & 1.05 & 3.72 & 372.1 & 75 & 0.53 & 12 & 10 & 62.3 \\
\hline 5 & 48 & 0.81 & 714.3 & 11.29 & 1.30 & 4.15 & 402.2 & 75 & 0.61 & 11 & 9 & 58.5 \\
\hline 6 & 48 & 1.05 & 641.3 & 11.19 & 1.30 & 5.11 & 332.4 & 60 & 0.80 & 10 & 8 & 63.4 \\
\hline 7 & 53 & 0.65 & 706.5 & 12.91 & 2.31 & 7.35 & 413.0 & 40 & 1.06 & 6 & 5 & 59.8 \\
\hline 8 & 53 & 0.81 & 698.7 & 13.15 & 2.54 & 7.94 & 379.2 & 40 & 1.17 & 5.5 & 4.5 & 57.1 \\
\hline 9 & 53 & 1.05 & 705.2 & 11.38 & 3.31 & 9.41 & 329.4 & 40 & 1.60 & 4.5 & 3.5 & 62.7 \\
\hline 10 & 63 & 0.65 & 706.5 & 10.25 & 9.28 & 18.61 & 334.1 & 20 & 3.46 & 2 & 1.5 & 61.0 \\
\hline 11 & 63 & 0.81 & 706.5 & 10.25 & 9.28 & 19.90 & 307.3 & 20 & 3.94 & 2 & 1.5 & 61.0 \\
\hline 12 & 63 & 1.05 & 706.5 & 08.87 & 11.63 & 21.35 & 277.7 & 20 & 4.56 & 1.5 & 1 & 61.7 \\
\hline
\end{tabular}

Average drying rate (ADR), \% db/min, constant drying rate (DRc), \% $\mathrm{db} / \mathrm{min}$, the drying constant $(\mathrm{K}), 1 / \mathrm{h}$, critical moisture content time (CMCT), $\mathrm{h}$ and total drying time (TDT), $\mathrm{h}$ were analyzed by using of multiple regression analysis to study the effect of drying air temperature and air flow rate on marigold petals drying characteristics.

The following formulas in Table (2) illustrate the multiple regressions for the above variables at different levels of drying air temperature (T), ${ }^{\circ} \mathrm{C}$ and different levels of airflow rate $(\mathrm{Qe}), \mathrm{cu}-\mathrm{m} / \mathrm{min}$.:

Table (2): The multiple regressions for the variables at different levels of drying air temperature and airflow rate.

\begin{tabular}{|l|l|c|c|c|}
\hline Parameter & \multicolumn{1}{|c|}{ The formula of the multiple regression } & $\mathbf{R}^{2}$ & $\begin{array}{l}\text { The formula after eliminating the } \\
\text { airflow rate }(Q e) \text { from regression }\end{array}$ & $\mathbf{R}^{2}$ \\
\hline ADR & $A D R=-23.675+0.489 T+2.414 Q e$ & 0.901 & $A D R=-21.654+0.489 T$ & 0.890 \\
\hline DRc & $D R_{C}=-45.953+0.962 T+5.935 Q e$ & 0.958 & $D R_{C}=-40.987+0.962 T$ & 0.948 \\
\hline K & $K=-10.128+0.200 T+1.666 Q e$ & 0.903 & $K=-8.734+0.200 T$ & 0.873 \\
\hline CMCT & $C M C T=379.113-5.543 T-29.605 Q e$ & 0.799 & $C M C T=354.343-5.543 T$ & 0.788 \\
\hline TDT & $T D T=58.629-0.877 T-4.317 Q e$ & 0.859 & $T D T=55.017-0.877 T$ & 0.848 \\
\hline
\end{tabular}


Multiple regression analysis showed that air flow rate $(\mathrm{Qe})$ in the range of $(0.65-1.05 \mathrm{cu}-\mathrm{m} / \mathrm{min})$ had no significant effect on the above characteristics because of the thin layer drying of marigold petals.

There was negligible effect of airflow rate on the drying characteristics according to report of (Hall and Pear, 1980). But drying air temperature (T) had a high significant effect on the above drying characteristics. Drying constant (K), average drying rate (ADR) and constant drying rate $\left(\mathrm{DR}_{\mathrm{C}}\right)$ had a highest values of 3.462-4.560 1/h, 9.28$11.63 \%, \mathrm{db} / \mathrm{min}$ and $18.61-21.35 \%, \mathrm{db} / \mathrm{min}$ at drying air temperature $\mathrm{T}=63^{\circ} \mathrm{C}$ and airflow rate $(\mathrm{Qe})$ range of $0.65-1.05 \mathrm{cu}-\mathrm{m} / \mathrm{min}$, respectively.

They had an increasing relationship versus drying air temperature. While , the critical moisture content time (CMCT) and total drying time (TDT) had the lowest values of 20.0 and 1.5-2.0 $\mathrm{min}$ at drying air temperature $\mathrm{T}=63^{\circ} \mathrm{C}$ and airflow rate (Qe) range of 0.65-1.05 cu-m/min, respectively. They had a decreasing relation with drying air temperature.

The empirical equations were developed between the moisture content $\mathrm{db}, \%$ and drying time at drying rate stages for all levels of drying air temperature $(\mathrm{T})$ and all levels of airflow rate $(\mathrm{Qe})$ for the electrical laboratory drying system as following:

\section{-At constant drying rate stage:}

$M C(d b)=-C 0+C 1 \times t$

(from $t=0$ to $t=C M C T \min )$

\section{-At falling drying rate stage}

$$
\begin{aligned}
& M C(d b)=F 0 \times e^{-F 1 t} \\
& (\text { from } t=0 \text { to } t=C M C T \text { min })
\end{aligned}
$$

Where,

C0, C1, F0 and F1 are experimental constants. These constant values were indicated in Table (3). Also, the regression coefficient $\mathrm{R}^{2}$ were recorded in Table (3). 
Table (3): Experimental constants for moisture content-drying time equations at different levels of drying air temperatures and air flow rates in electrical laboratory dryer according to drying rate stages of marigold petals.

\begin{tabular}{|c|c|c|c|c|c|c|c|c|}
\hline \multirow[t]{2}{*}{ NO } & \multirow[t]{2}{*}{$\mathbf{T},{ }^{\circ} \mathbf{C}$} & \multirow[t]{2}{*}{$\mathbf{Q e}$} & \multicolumn{3}{|c|}{$\begin{array}{l}\text { The constants for constant } \\
\text { drying rate stage formula }\end{array}$} & \multicolumn{3}{|c|}{$\begin{array}{c}\text { The constants for falling } \\
\text { drying rate stage formula }\end{array}$} \\
\hline & & & CO & C1 & $\mathbf{R}^{2}$ & F0 & F1 & $\mathbf{R}^{2}$ \\
\hline 1 & 43 & 0.65 & 624.64 & 1.4526 & 0.999 & 640.85 & 0.0032 & 0.985 \\
\hline 2 & 43 & 0.81 & 654.72 & 1.7639 & 1.000 & 655.50 & 0.0038 & 0.988 \\
\hline 3 & 43 & 1.05 & 680.64 & 2.5046 & 0.997 & 612.24 & 0.0043 & 0.979 \\
\hline 4 & 48 & 0.65 & 640.74 & 3.7104 & 0.999 & 622.27 & 0.0071 & 0.991 \\
\hline 5 & 48 & 0.81 & 714.33 & 4.1266 & 1.000 & 736.68 & 0.0083 & 0.983 \\
\hline 6 & 48 & 1.05 & 640.86 & 5.1456 & 1.000 & 585.21 & 0.0096 & 0.952 \\
\hline 7 & 53 & 0.65 & 706.45 & 7.3437 & 1.000 & 697.80 & 0.0139 & 0.991 \\
\hline 8 & 53 & 0.81 & 698.72 & 8.0048 & 1.000 & 669.32 & 0.0155 & 0.990 \\
\hline 9 & 53 & 1.05 & 705.15 & 9.3933 & 1.000 & 716.68 & 0.0204 & 0.994 \\
\hline 10 & 63 & 0.65 & 706.45 & 18.663 & 0.999 & 1058.85 & 0.0574 & 0.976 \\
\hline 11 & 63 & 0.81 & 706.45 & 19.956 & 1.000 & 1077.78 & 0.0610 & 0.998 \\
\hline 12 & 63 & 1.05 & 706.45 & 21.428 & 1.000 & 1339.25 & 0.7760 & 0.967 \\
\hline
\end{tabular}

$\mathrm{C} 0, \mathrm{C} 1, \mathrm{~F} 0$ and $\mathrm{F} 1$ are experimental constants

\section{B- Effect of drying system on sensory characteristics of dried marigold petals.}

Four exporters of medicinal plants evaluated the color, appearance and general quality of marigold petals according to a degree out of ten to study the effect of different drying systems under tests on sensory characteristics of marigold petals. The means of these evaluations are recorded in Table (4).

Table (4): Sensory characteristics data of dried marigold petals

\begin{tabular}{|c|c|c|c|}
\hline Electrical-laboratory drying system & $\begin{array}{c}\mathrm{ECE} \\
\text { (degree) }\end{array}$ & $\begin{array}{c}\mathbf{E A E} \\
\text { (degree) }\end{array}$ & $\begin{array}{c}\mathrm{EQE} \\
\text { (degree) }\end{array}$ \\
\hline$T=43 C, Q e=0.65 \mathrm{cu}-\mathrm{m} / \mathrm{min}$ & 7.50 & 3.50 & 3.25 \\
\hline$T=43 \mathrm{C}, \mathrm{Qe}=0.81 \mathrm{cu}-\mathrm{m} / \mathrm{min}$ & 7.50 & 3.75 & 3.75 \\
\hline$T=43 C, Q e=1.05 \mathrm{cu}-\mathrm{m} / \mathrm{min}$ & 7.75 & 3.75 & 4.00 \\
\hline$T=48 C, Q e=0.65 \mathrm{cu}-\mathrm{m} / \mathrm{min}$ & 8.25 & 4.25 & 3.75 \\
\hline$T=48 C, Q e=0.81 \mathrm{cu}-\mathrm{m} / \mathrm{min}$ & 8.50 & 4.50 & 4.25 \\
\hline$T=48 C, Q e=1.05 \mathrm{cu}-\mathrm{m} / \mathrm{min}$ & 8.50 & 4.50 & 4.75 \\
\hline$T=53 \mathrm{C}, Q \mathrm{e}=0.65 \mathrm{cu}-\mathrm{m} / \mathrm{min}$ & 8.50 & 6.50 & 6.75 \\
\hline $\mathrm{T}=53 \mathrm{C}, \mathrm{Qe}=0.81 \mathrm{cu}-\mathrm{m} / \mathrm{min}$ & 8.75 & 6.75 & 7.00 \\
\hline$T=53 \mathrm{C}, \mathrm{Qe}=1.05 \mathrm{cu}-\mathrm{m} / \mathrm{min}$ & 8.75 & 7.00 & 7.25 \\
\hline$T=63 \mathrm{C}, \mathrm{Qe}=0.65 \mathrm{cu}-\mathrm{m} / \mathrm{min}$ & 9.25 & 8.50 & 8.00 \\
\hline$T=63 \mathrm{C}, Q \mathrm{e}=0.81 \mathrm{cu}-\mathrm{m} / \mathrm{min}$ & 9.00 & 8.00 & 8.50 \\
\hline$T=63 \mathrm{C}, Q \mathrm{e}=1.05 \mathrm{cu}-\mathrm{m} / \mathrm{min}$ & 9.25 & 8.75 & 9.00 \\
\hline
\end{tabular}


The multiple regression analysis was used to express the relationship between drying air temperature $(\mathrm{T}),{ }^{\circ} \mathrm{C}$ with airflow rate $(\mathrm{Qe})$, and exports evaluations of sensory characteristics. The multiple regression analysis explained that airflow rate $(\mathrm{Qe})$ had no significant effect on the color, the appearance and the general quality of marigold petals.

Drying air temperature $(\mathrm{T}),{ }^{\circ} \mathrm{C}$ had a high significant increasing effect on all sensory characteristics due to reduce the drying period at the high temperature levels.

The color, the appearance and the general quality of marigold petals had the highest values of 9.00-9.25 degree, 8.00-8.75 degree, $\mathrm{db} / \mathrm{min}$ and 8.00-9.00 degree at drying air temperature $\mathrm{T}=63{ }^{\circ} \mathrm{C}$ and airflow rate (Qe), range of $0.65-1.05$, respectively. Drying air temperature $(\mathrm{T}),{ }^{\circ} \mathrm{C}$ had a high significant increasing effect on all sensory characteristics due to reduce the drying period in the high temperature levels.

\section{C-Effect of Electrical Laboratory Drying System on Chemical Characteristic of Dried marigold petals:}

The main chemical contents were total carotene as Charlchat reported in 1991. The carotene concentration (Con), $\mathrm{mg} / \mathrm{g}$ for medicinal marigold petals was estimated as recorded in Table (5) through electrical laboratory drying system treatments under investigation and control treatment of fresh marigold petals. To compare the electrical laboratory drying treatments with, control the ratio between carotene concentration (Con), $\mathrm{mg} / \mathrm{g}$ of drying treatment and carotene concentration (Con), mg/g of control treatment were calculated and recorded in Table (5). The general trend of carotene concentration varied according to drying system.

Multiple regression analysis was expressed to study the effect of electrical laboratory drying system on carotene concentration (Con), $\mathrm{mg} / \mathrm{g}$ of dried marigold petals through two control factors; drying air temperature $\mathrm{T}\left(63,53,48\right.$ and $\left.43^{\circ} \mathrm{C}\right)$ and air flow rate Qe $(1.05,0.81$, and $0.65 \mathrm{cu}-\mathrm{m} / \mathrm{min})$. 
Table (5): Chemical characteristics for medicinal marigold petals with control treatment.

\begin{tabular}{|c|c|c|c|c|}
\hline NO & Treatment & $\begin{array}{c}\text { Con. } \\
\text { (mg/gm) }\end{array}$ & $\begin{array}{c}\text { Rc } \\
\text { (decimal) }\end{array}$ & $\begin{array}{c}\text { Degree of } \\
\text { unchanging }\end{array}$ \\
\hline 1 & Control & 332.39 & 1.0000 & \\
\hline 2 & Electrical-laboratory drying system & & & \\
\hline $\mathbf{a}$ & $\mathrm{T}=43 \mathrm{C}, \mathrm{Qe}=0.65 \mathrm{cu}-\mathrm{m} / \mathrm{min}$ & 236.31 & 0.7110 & good \\
\hline $\mathbf{b}$ & $\mathrm{T}=43 \mathrm{C}, \mathrm{Qe}=0.81 \mathrm{cu}-\mathrm{m} / \mathrm{min}$ & 236.18 & 0.7106 & good \\
\hline c & $\mathrm{T}=43 \mathrm{C}, \mathrm{Qe}=1.05 \mathrm{cu}-\mathrm{m} / \mathrm{min}$ & 237.35 & 0.7141 & good \\
\hline $\mathbf{d}$ & $\mathrm{T}=48 \mathrm{C}, \mathrm{Qe}=0.65 \mathrm{cu}-\mathrm{m} / \mathrm{min}$ & 267.79 & 0.8057 & Very good \\
\hline e & $\mathrm{T}=48 \mathrm{C}, \mathrm{Qe}=0.81 \mathrm{cu}-\mathrm{m} / \mathrm{min}$ & 269.42 & 0.8106 & Very good \\
\hline $\mathbf{f}$ & $\mathrm{T}=48 \mathrm{C}, \mathrm{Qe}=1.05 \mathrm{cu}-\mathrm{m} / \mathrm{min}$ & 271.51 & 0.8169 & Very good \\
\hline $\mathbf{g}$ & $\mathrm{T}=53 \mathrm{C}, \mathrm{Qe}=0.65 \mathrm{cu}-\mathrm{m} / \mathrm{min}$ & 284.83 & 0.8569 & excellent \\
\hline $\mathbf{h}$ & $\mathrm{T}=53 \mathrm{C}, \mathrm{Qe}=0.81 \mathrm{cu}-\mathrm{m} / \mathrm{min}$ & 290.62 & 0.8743 & excellent \\
\hline $\mathbf{i}$ & $\mathrm{T}=53 \mathrm{C}, \mathrm{Qe}=1.05 \mathrm{cu}-\mathrm{m} / \mathrm{min}$ & 289.72 & 0.8716 & excellent \\
\hline $\mathbf{j}$ & $\mathrm{T}=63 \mathrm{C}, \mathrm{Qe}=0.65 \mathrm{cu}-\mathrm{m} / \mathrm{min}$ & 308.33 & 0.9276 & excellent \\
\hline $\mathbf{k}$ & $\mathrm{T}=63 \mathrm{C}, \mathrm{Qe}=0.81 \mathrm{cu}-\mathrm{m} / \mathrm{min}$ & 310.35 & 0.9337 & excellent \\
\hline $\mathbf{l}$ & $\mathrm{T}=63 \mathrm{C}, \mathrm{Qe}=1.05 \mathrm{cu}-\mathrm{m} / \mathrm{min}$ & 312.29 & 0.9395 & excellent \\
\hline
\end{tabular}

The following multiple regression equation explained the relationship between carotene concentration (Con), $\mathrm{mg} / \mathrm{g}$ versus drying air temperature $\mathrm{T}{ }^{\circ} \mathrm{C}$ and air flow rate $\mathrm{Qe}, \mathrm{cu}-\mathrm{m} / \mathrm{min}$.

$$
\begin{aligned}
& \text { Con }=-87.12+3.52 T+8.19 Q e \\
& R^{2}=0.9266
\end{aligned}
$$

After removing the airflow rate $(\mathrm{Qe})$ from the regression, the equation becomes:

$$
\begin{aligned}
& \text { Con }=-93.98+3.52 T \\
& \mathbf{R}^{2}=0.9241
\end{aligned}
$$

Multiple regression analysis showed that the drying air temperature $\mathrm{T}^{\circ} \mathrm{C}$ had a significant increasing effect on carotene concentration (Con), mg/g due to reduced drying time, while the airflow rate $(\mathrm{Qe})$ in range of $(0.65-$ $1.05 \mathrm{cu}-\mathrm{m} / \mathrm{min}$ ) had no significant effect.

The carotene concentration (Con) had the best value range of 310.35$312.29 \mathrm{mg} / \mathrm{g}$ at drying air temperature $\mathrm{T}=63^{\circ} \mathrm{C}$ and airflow rate $(\mathrm{Qe})$ 
range of (0.65-1.05) cum/min) with an excellent unchanging comparing with control treatment which had value of $332.39 \mathrm{mg} / \mathrm{g}$.

\section{CONCLUSION}

The electrical drying system in laboratory experiments was used to heat the drying air. Two controlled factors were investigated to study the drying characteristics for marigold petals, airflow rate (Qe), cu-m/min. at three levels of $(0.65,0.81$ and $1.05 \mathrm{cu}-\mathrm{m} / \mathrm{min}$.) and drying air temperature $(\mathrm{T})$ at four levels of $\left(43,48,53\right.$ and $\left.63^{\circ} \mathrm{C}\right)$. The conclusion of the results were;

1- The initial moisture content (IMC) varied between $624.64 \%, \mathrm{db}$ (86.20\%wb) and $706.45 \%, \mathrm{db}(87.60 \% \mathrm{wb})$.

2- The equilibrium moisture content (EMC) had a limited value between $8.87 \%, \mathrm{db}$ and $14.73 \%, \mathrm{db}(8.15 \%$, wb and $12.84 \%$, $\mathrm{wb})$

3- The minimum average relative humidity of ambient air was 57.1 $\%$ while the maximum average relative humidity of ambient air was $66.5 \%$.

4- The critical moisture content value was limited between 277.69 $\%, \mathrm{db}(73.52 \%, \mathrm{wb})$ and $408.45 \%, \mathrm{db}(80.33 \% \mathrm{wb})$.

5- Average drying rate (ADR), \% db/min. constant drying rate (DRc), \% db/min, the drying constant $(\mathrm{K}), 1 / \mathrm{h}$, critical moisture content time (CMCT), $\mathrm{h}$ and total drying time (TDT), $\mathrm{h}$ were analyzed by using multiple regression analysis to study the effect of drying air temperature and air flow rate on marigold petals drying characteristics.

6- The analysis showed that air flow rate (Qe) had no significant effect on the above characteristics because of the thin layer drying of marigold petals. There was negligible effect on the drying characteristics according to the report of (Hall and Pear, 1980). But, drying air temperature $(T)$ had a high significant effect on the above dring characteristics. Drying constant (K), average drying rate (ADR) and constant drying rate (DRc) had the highest values of $3.462-4.5601 / \mathrm{h}, 9.28-11.63 \%, \mathrm{db} / \mathrm{min}$ and $18.61-21.35 \%, \mathrm{db} / \mathrm{min}$ at drying air temperature $\mathrm{T}=63^{\circ} \mathrm{C}$ 
and airflow rate (Qe) range of $0.65-1.05 \mathrm{cu}-\mathrm{m} / \mathrm{min}$, respectively. They had an increasing relationship versus drying air temperature. While, the critical moisture content time (CMCT) and total drying time (TDT) had the lowest values of $20.0 \mathrm{~min}$ and $1.5-2.0 \mathrm{~h}$ at drying air temperature $\mathrm{T}=63^{\circ} \mathrm{C}$ and airflow rate (Qe) range of $0.65-1.05 \mathrm{cu}-\mathrm{m} / \mathrm{min}$, respectively. They had a decreasing relation with drying air temperature.

Finally, applying the ELDS of marigold petals at high levels of drying air $\left(63^{\circ} \mathrm{C}\right)$ and air flow rate range of $\left.0.65-1.05 \mathrm{cu}-\mathrm{m} / \mathrm{min}\right)$ is recommended to utilize in commercial drying.

\section{REFERENCES}

Agricultural Statistics (1994). The Ministry of Agriculture and land Reclamation, Economic Affairs Sector.

Agricultural Statistics (1984). The Ministry of Agriculture and land Reclamation, Economic Affairs Sector.

Baily, N; I. (1994). Statistical methods in biology. Cambridge U. Press, $3^{\text {rd }}$ edition, N. Y., USA.

Buser, M.D.; M.L. Stone; G.H. Bruswitz; N.O. Moness and D.P. Whitelock. (1999). Thin-layer drying of marigold flowers and flower components for petals removal. Transactions of the ASAE. 42 (5):1367-1373

C.L.A.C. (2000). The Central Laboratory of Agricultural Climate, Douky, Giza, Egypt.

Charlchat, J.C; R.P. Garry and A. Michet. (1991). Chemical composition of essential oil of Calendula officinalis. Flower and Frgrance Journal. 6(3): 189-192. (CF Horticultural Abstract. 1992. 62 (4): 325-389).

E.E.D.C. (1998). Egyptian Exports Development Center, Giza, Egypt.

Hall, C.W. and P. E. Pear. (1980). Drying and storage of agricultural crops, AVI, Publishing Company, Inc., West Port conc., USA. 
Henderson, S.M. and R. L. Perry. (1976). Agriculture process engineering. Published by the AVI Publishing Company, Inc., Library of Congress, Washington, USA.

Kramer, A and B. Twigg (1974). Quality control for the food industry. The AVI Pub. Co. Inc., West port. Connecticut. USA.

Othman, A. A. (1996). Utilization of solar energy in drying of some medicinal plants. PH. D. Th. Fac. Ag., Fayoum, Cairo University, Egypt.

\section{الملخص العربي}

تطوير خصائص معاملات التجفيف لبتلات نبات الأقحوان باستخدام نظام

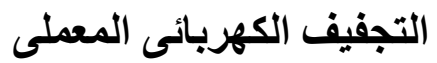

شكر ، عزت عبد الغفار ، رشوان و شعبد المعبان

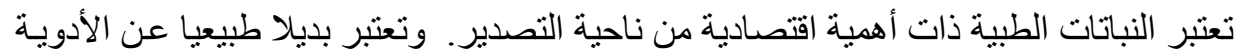

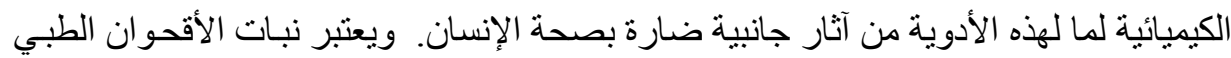

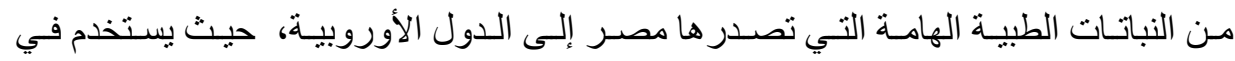

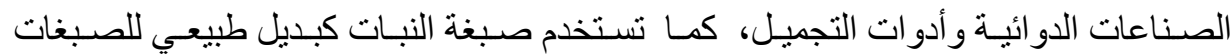

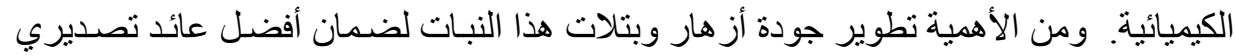

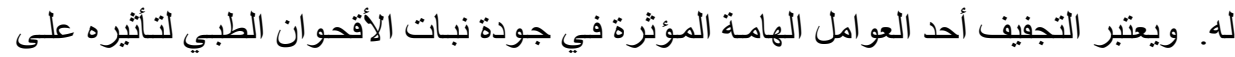

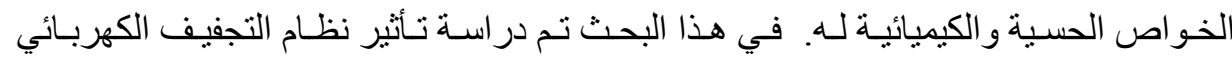
المعملي على كل من الخو اص التجفيفية و الحسية و الكيميائبة لبتلات نبات التيات الأقحو ان.

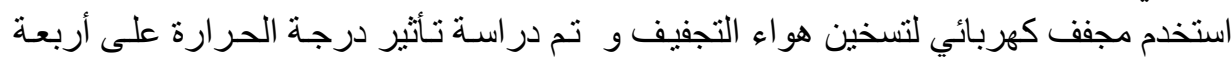

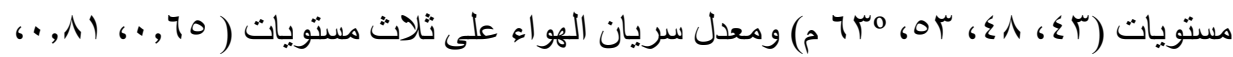

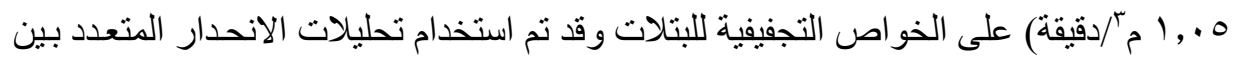
درجة حر ارة التجفيف ومعدل سريان الهو اء من جهة ومنوسط معدل التجفيف، معدل التجفيف

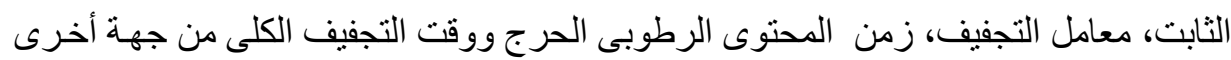
و و كانت النتائج كالآتي:

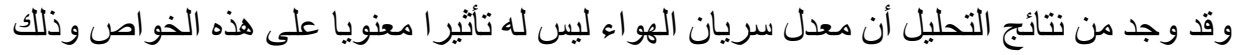

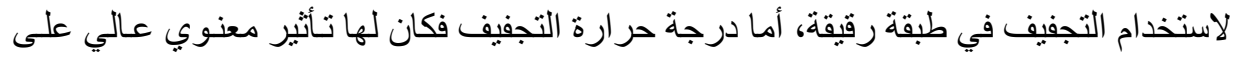

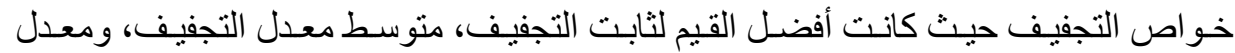

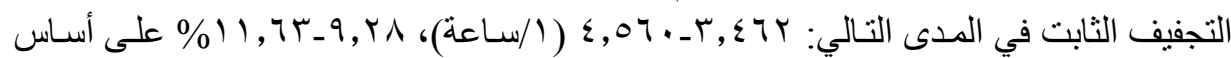

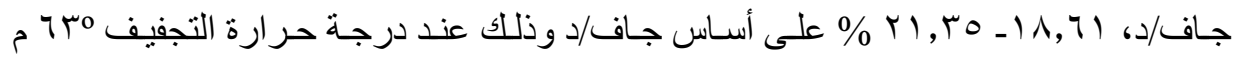

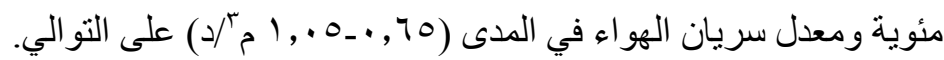

*قسم الهندسة الزراعية والحيوية ـ كلية الزراعة (الثاطبي) - جامعة الإسكندرية ـ مصر. 


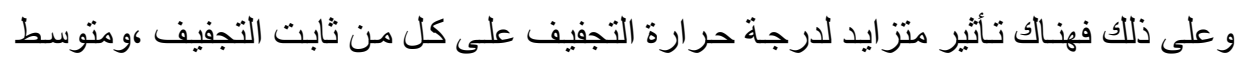

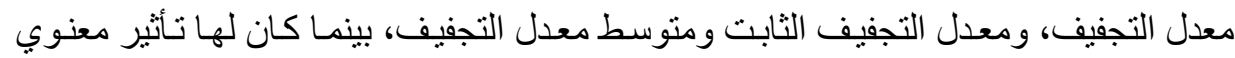

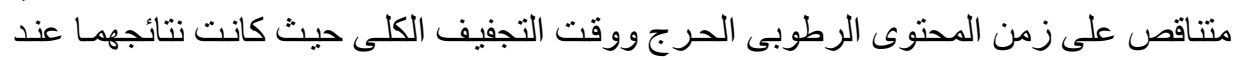

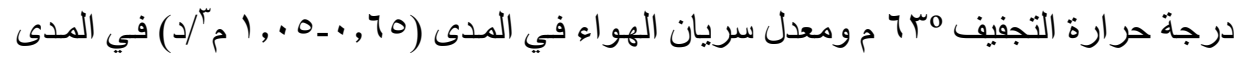

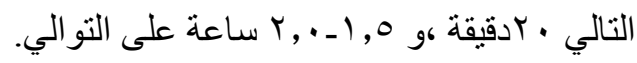

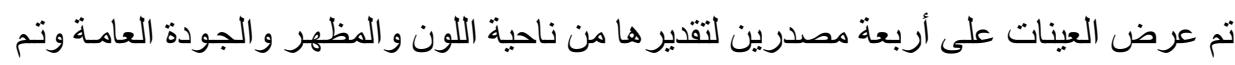

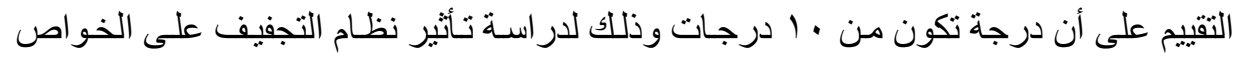

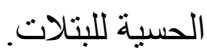

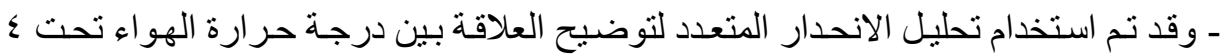

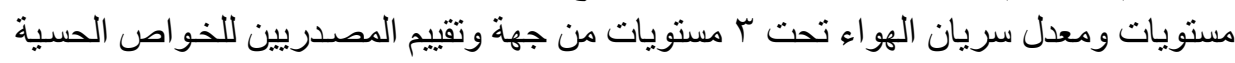

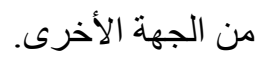

ـ كان من نتائج التحليل عدم وجود تأثثر معنوي لمعدل سريان الهواء على الخو اص الحسية لالبتلات.

ـ درجة حر ارة التجفيف كان لها تأثير ايجابي واضح على الخو اص الحسية للبتلات.

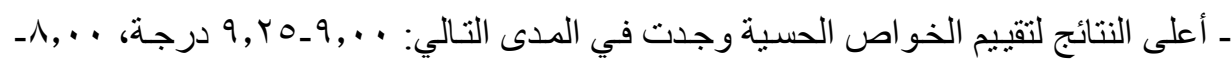

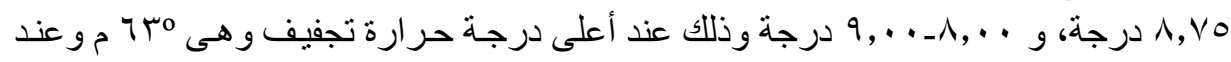

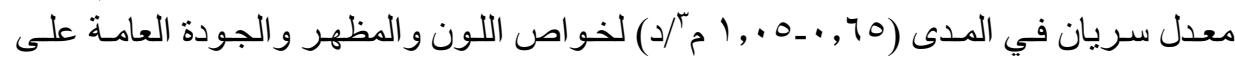
الترتيب. 